\title{
Conventional and organic cropping systems at Suitia VII: Earthworms
}

\author{
VISA NUUTINEN and JARI HAUKKA* \\ Agricultural Research Centre, Institute of Plant Protection, \\ SF-31600 Jokioinen, Finland
}

\begin{abstract}
The earthworm communities were studied in an experiment with eight cropping systems (four conventional and four organic), carried out on silty clay soil. Earthworms were sampled during the three last years of the seven year experiment. Samples were taken with formalin in the autumns of 1986 and 1987 (one replicate of the experiment) and in that of 1988 with formalin and by taking soil-cores (all three replicates).

Aporrectodea caliginosa (Sav.) was dominant in all cropping systems. The rest of the identified individuals were Lumbricus rubellus (Hoff.) and L. terrestris (L.). A few L. castaneus (Sav.) were also found. There were no clear differences in the species composition between the conventional and organic cropping systems. Application of slurry caused a drop in the proportion of Lumbricus. Low total numbers were observed in 1987, possibly due to high winter mortality. In 1988, the average number (and SE) of earthworms was $23(11.2)-92(49.8)$ ind. $\mathrm{m}^{-2}$ and their total dry weight $1.0(0.54)-3.2(1.53) \mathrm{g} \mathrm{m}^{-2}$. The average number of cocoons in 1988 ranged from $5(2.5)$ to $52.5(26.3)$ coc. $\mathrm{m}^{-2}$. The highest abundances of earthworms and cocoons were observed in the organically cultivated vetch ley. The differences between the treatments in worm abundance were not statistically discernible. The mean size (mg dwt) of juvenile and adult $A$. caliginosa was similar in different cropping systems.

The abundance patterns of earthworms differed in the replicates. This was related to the confounding effects of local water-logging and soil compaction in the field. Consistent differences in the soil conditions of the cropping systems resulting from the activity of earthworms are unlikely.
\end{abstract}

Index words: earthworms, cropping systems, Lumbricidae, Aporrectodea, Lumbricus, water-logging

\section{Introduction}

The alternatives to modern chemicalized methods of crop cultivation rely on active soil flora and fauna. Plant nutrients are not given

* Present address: National Public Health Institute, Kalliolinnantie 4, SF-00140 Helsinki, Finland directly as inorganic fertilisers but in organic amendements, which are mineralized by the soil's decomposer web. Little or no use of biocides and crop rotations with leys constitute an attempt to guarantee the biological activity of the soil. These practices, it is hoped, bring about fertile soil in a sustainable way. 
Abundance of earthworms is one of the particularly desirable soil characteristics (e.g. Arden-Clarke and Hodges 1988), as apart from contributing to the breakdown of organic matter, earthworms ameliorate a number of soil features (reviewed in LEE 1985).

The differences between conventional and organic farming are potential effectors of earthworm abundance. The quality and quantity of nitrogenous fertilisers are known to affect both the abundance of earthworms and the species composition of the earthworm community (EDwARDS and LOFTY 1982, LoFsHolmin 1983 a, LeE 1985). Crop rotation also affects earthworm populations. For example, the number of earthworms often increases in leys which are not ploughed yearly (EDwards 1983), the leguminous leys being particularly suitable for earthworms (BATES 1933, Boström 1988). The biocides used in plant protection, one prominent feature of conventional high input farming, influence earthworms. The most harmful substances are found among fungicides, while herbicides and insecticides, in normal doses, seem to be of little or no harm (ANDRÉN and STEEN 1978, LEE 1985).

Below we summarise the observations on the earthworm communities in an experiment where the effects of conventional and organic cropping systems on soil fertility were investigated. The study is merely descriptive. The first sampling was done in the fifth year and the last in the final year of the experiment. All three replicates were sampled only at the final occasion. As there are no data on the whole six-year rotations of the experiment, the reasons behind the patterns of abundance and community composition cannot be discussed with certainty, nor can the consistency of patterns be established.

\section{Materials and methods}

\section{Experiment}

The experimental field is situated at the Suitia Farm, in Siuntio, Southern Finland $\left(60^{\circ} 11^{\prime} \mathrm{N}, 24^{\circ} 10^{\prime} \mathrm{E}\right)$. The soil of the field is silty clay (clay-\% 51-62). Details on the characteristics and cultivation history of the experimental field and weather conditions in the area are given in HannukKala et al. (1990). The experiment, started in 1982, consists of eight cropping systems, four organic and four conventional, each having a six-year crop sequence. The number of replicates is three. The cropping systems are nested in the organic and conventional groups of systems. HannukKala et al. (1990) describe in detail the systems and the experimental design. Earthworms were always sampled on the ' $b$ ' side in each plot. The cropping systems and their symbols are as follows (applied fertilisers in brackets):

\section{Conventional cropping}
A1 = barley monoculture $(\mathrm{N}-\mathrm{P}-\mathrm{K})$
$\mathrm{A} 2$ = cereal production $\quad(\mathrm{N}-\mathrm{P}-\mathrm{K})$
A3 $=$ diverse plant
(N-P-K) production
B $=$ cattle farm
$($ slurry $+\mathrm{N}-\mathrm{P}-\mathrm{K})$

Organic cropping

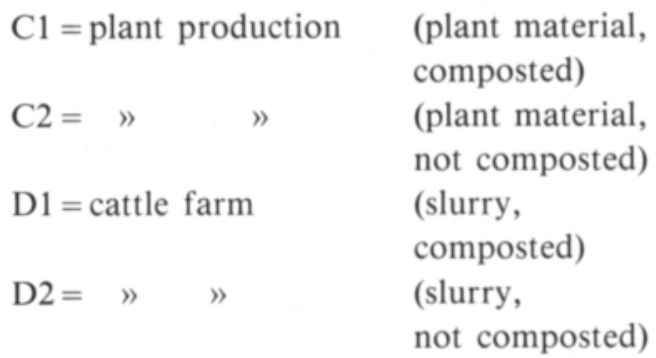

Similar farm machinery was used in all systems. In organic cropping, no biocides were used, while in conventional cropping various herbicides, fungicides and, to a lesser degree insecticides were applied (HANNUKKALA et al. 1990).

\section{Sampling}

\section{General}

Two samples were taken from the both ends of each plot ca. four metres in from the plot margin, avoiding sites where water was stand- 
ing at the wheel tracks. Thus the sample size per plot was four, and the total number of samples $8 \times 4=32$ in 1986 and 1987, when only replicate $I$ was sampled, and $3 \times 8 \times 4$ $=96$ in 1988, when all three replicates were sampled. The sample size was not determined by any statistical scrutiny. Four samples per plot were considered sufficient because of practical and economic limitations facing the sampling effort. Sampling was done in August right after the harvest and before cultivations (1986: 27th August; 1987: 27th August; 1988: 15th-18th August). In the plots growing potato, leys or leguminous green manures, the plants were growing during the sampling.

\section{Sampling method}

A wooden frame enclosing a square of $1 \mathrm{~m}^{2}$ was placed on the ground at the site of sampling. Often the frame could not be fitted tightly against the soil surface due to roughness and hardness of the soil. Straw and/or growing plants were cut, and plant residues removed from the soil surface. The square was divided into equal halves by stretching an iron wire between opposite sides of the frame. The sampling unit covered an area of $0.5 \mathrm{~m}^{2}$, from which earthworms were sampled with the formalin (1986 and 1987) or the combined formalin/soil core method (1988) (BouCHÉ and GARDNER 1984).

The formalin solution was applied four times. Each time approximately 10 litres was poured from a sprinkling can on the $0.5 \mathrm{~m}^{2}$ area. $0.25 \%$ solution was used for the first two applications and $0.50 \%$ solution for the last two. For 10 minutes after each application, the emerging earthworms were picked up and placed into small plastic bottles filled with $4 \%$ formalin. One person simultaneously sampled both sides of the frame in two adjacent plots.

In 1988, two soil cores (diameter $14.5 \mathrm{~cm}$, depth ca. $20 \mathrm{~cm}$ ) were taken from the middle of the $0.5 \mathrm{~m}^{2}$ area after the formalin application. The soil samples were stored on the field for up to two days before they were taken to the laboratory and submerged in $4 \%$ formalin for preservation. About $1 \mathrm{dl}$ of $\left(\mathrm{NaPO}_{3}\right)_{6}$ per 10 litres of solution was added to accelerate the dispersion of clay. The samples were kept covered outdoors, and they were mixed gently at intervals of a few days. After four weeks the earthworms and cocoons were wet sieved from the soil samples and preserved in $4 \%$ formalin. The soil typically formed small tight clods in the sieving apparatus, and it was found impractical to try to make all of them disperse. It was checked that the clods were not formed particularly around worms or cocoons.

\section{Treatment of the material}

The material was kept in formalin at $10^{\circ} \mathrm{C}$ for at least four weeks before the identification and weight determinations. Adults and juveniles were identified according to SIMS and Gerard (1985), juveniles only to genus. The only representative of adult Aporrectodea in the field was $A$. caliginosa; the juvenile Aporrectodea were regarded to be of the same species. The morphs of $A$. caliginosa (Bouché et al. 1988) were not treated separately, nor was the species of the cocoons determined. Only the total numbers and dry weights of worms are reported for 1986 and 1987.

After the identification of a worm its formalin weight was determined. The worms were then dried at $105^{\circ} \mathrm{C}$ for ca. 24 hours, and their dry weights measured. The weight estimates include the gut contents. Thirty earthworms of the 1986 material were accidentally lost before their dry weights were measured. For them, an estimated dry weight was calculated on the basis of the species-wise regressions of dry weight on formalin weight in the rest of the material for 1986. Data of 1987 were used for Lumbricus rubellus.

The frequencies per square meter were calculated separately for worms and cocoons; for worms the total dry weights were also calculated. Mean abundances for each plot were obtained from the four sample estimates. In 
each plot, the average size (mg dwt) was determined for adult and juvenile $A$. caligino$s a$, based on the pooled material of 1988 . ANOva was performed for the plot means of the 1988 material. The original values were $\log (x+1)$ (dry weights) or square root (numbers of individuals) transformed to homogenize the variances. To evaluate the occurrence of Aporrectodea and Lumbricus in chemically (A1-B) vs. organically (C1-D2) fertilised cropping systems and in the plots fertilised with slurry (B, D1, D2) vs. other plots, $2 \times 2$ frequency tables were formed of the pooled material of 1988. Logistic analysis (McCuLLAGH \& NELDER 1983) was then performed with the species group as the dependent dichotomic variable. The risk level was set at $5 \%$ in all analyses.

\section{Results}

Yearly changes of abundance in replicate I The soil moisture conditions were different
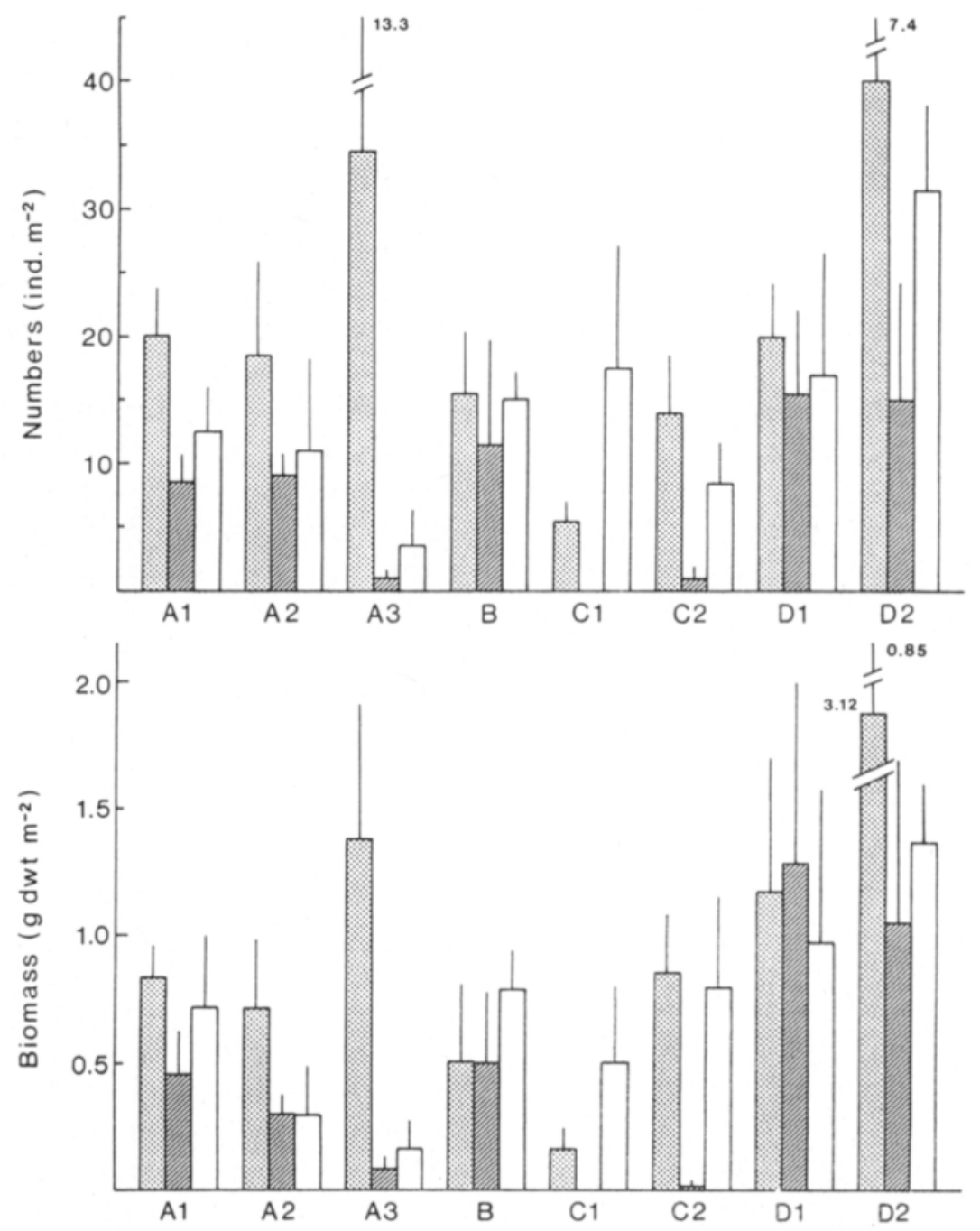

Fig. 1. Average number (ind. $\left.\mathrm{m}^{-2}(+\mathrm{SE})\right)$ and total dry weight $\left(\mathrm{g} \mathrm{m}^{-2}(+\mathrm{SE})\right)$ of earthworms in replicate $\mathrm{I}$ (stipled: 1986; hatched: 1987; open: 1988). The estimates are the means of four formalin samples. The symbols of the cropping systems are explained in the text. 
in the three autumns (HannukKala et al. 1990) and the efficiency of the formalin extraction probably was dissimilar in the different years. Thus the formalin estimates obtained in replicate I are compared only qualitatively. This renders the analysis meagre, but statistical testing is unwarranted. The total catch of individuals in the different years was 315 (1986), 123 (1987) and 232 (1988). Exceptionally high numbers were observed in 1986 at A3 and D2 (Fig. 1). Compared with 1986, the abundance was much smaller in 1987 in A3, C1 and C2. C1 was completely devoid of earthworms, and the three cropping systems had the lowest average of numbers and total dry weights in 1987. In 1988, the abundance of earthworms in A3 was still very low. This was no longer the case in $\mathrm{C} 1$ and $\mathrm{C} 2$.

\section{Species}

In 1988, the individuals of Aporrectodea caliginosa (Sav.) comprised $86 \%$ of the material (total of 1234 ind.). The rest of the identified individuals were Lumbricus terrestris (L.), L. rubellus (Hoff.) and juvenile Lumbricus. In addition, a few individuals of $L$. castaneus (Sav.) were found. $66 \%$ of all Lumbricus were juveniles identified only to genus.

In all cropping systems, the majority of the individuals was usually juvenile $A$. caligino$s a$, while adults of the species always formed the largest proportion of the total dry weight (Fig. 2). The proportion of the combined Lumbricus of the total number of individuals was lowest in B (1.4\%) and highest in C1 $(12.4 \%)$. The corresponding figure for the total dry weight was highest in D2 (14.7\%). Logistic analyses did not reveal statistically discernible difference in the occurrence of Aporrectodea and Lumbricus in organically vs. chemically fertilised cropping systems $(\mathrm{p}=0.08)$. In the cropping systems where slurry was applied, the proportion of Lumbricus was smaller than in the others $(\mathrm{p}<0.001)$.
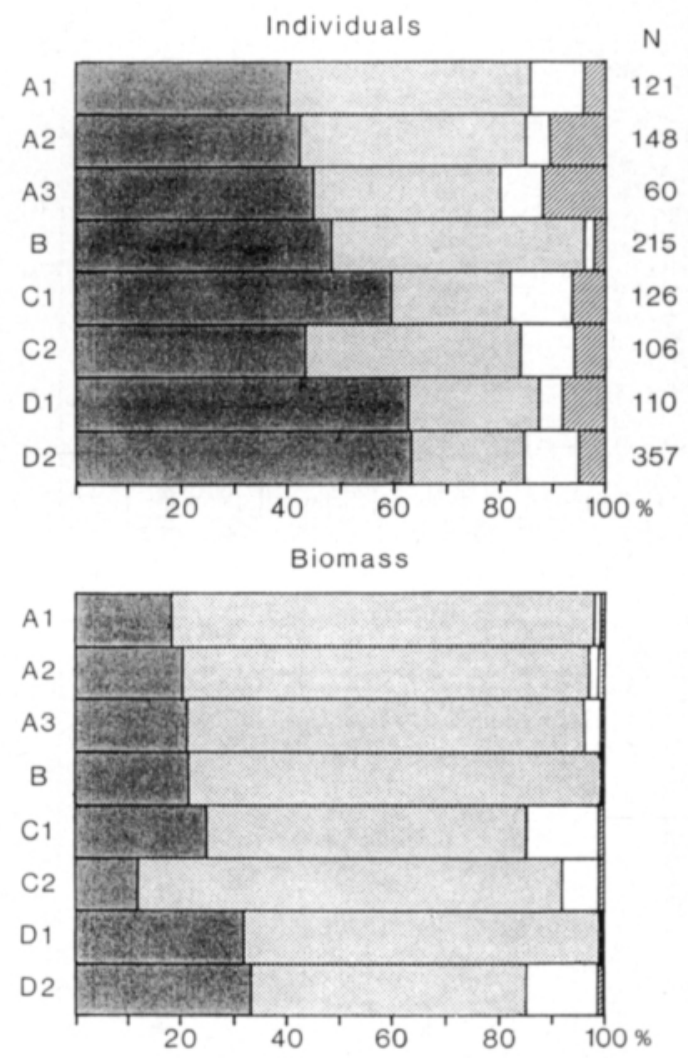

Fig. 2. Proportions of different groups of earthworms in the cropping systems in 1988. All individuals from the three replicates have been pooled. 'Biomass' refers to total dry weight. Dark grey: juvenile $A$. caliginosa; light grey; adult $A$. caliginosa; open: Lumbricus sp.; hatched: unidentified individuals. $\mathrm{N}=$ number of individuals. The symbols of the cropping systems are explained in the text.

\section{Abundances in 1988}

In the autumn of 1988 , when the whole experiment was sampled, the estimates of the total earthworm dry weights $\left(\mathrm{g} \mathrm{m}^{-2}\right.$ (SE)) ranged from $1.0(0.54)(\mathrm{A} 3)$ to $3.2(1.53)$ (D2) (Fig. 3). For the average number of individuals (ind. $\mathrm{m}^{-2}(\mathrm{SE})$ ) the lowest measurement was 23 (11.2) (A1) and the highest 92 (49.8) (D2) (fig. 3). The high mean abundances of D2 was due to the exceptionally high values in replicate III. There were no statistically discernible differences in the abundances between organic and conventional groups, and the same holds for the cropping systems within the organic and conventional groups (Table 1). The only significant source of variation 

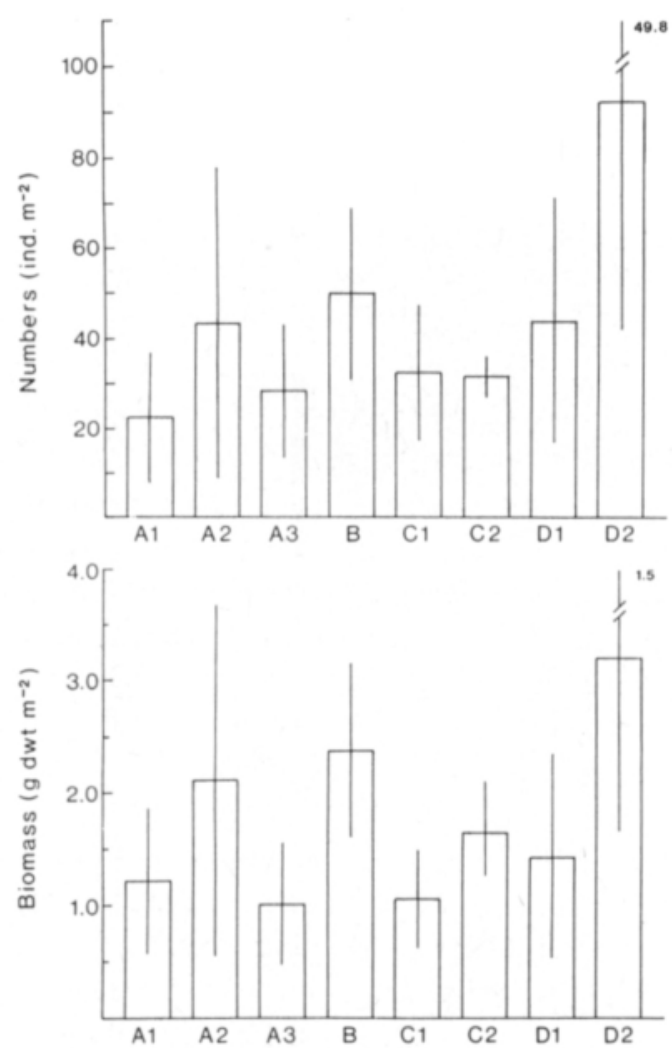

Fig. 3. Average number (ind. $\mathrm{m}^{-2}( \pm \mathrm{SE})$ ) and total dry weight $\left(\mathrm{g} \mathrm{m}^{-2}( \pm \mathrm{SE})\right)$ of earthworms in 1988 . The estimates are based on three replicate means each based on four formalin/soil-core-samples. The symbols of the cropping systems are explained in the text.

was the interaction between replicate and group of systems (Table 1). The average number of cocoons (coc. $\mathrm{m}^{-2}$ (SE)) ranged from 5 (2.5) (A3) to 52.5 (26.3) (D2) (Fig. 4). Again the high estimate in D2 was due to replicate III. Uniformly high cocoon numbers were obtained in D1. No ANOVA was performed on

Table 1. ANOVA table for the number of earthworms (ind. $\left.\mathrm{m}^{-2}\right)$ and their total dry weights $\left(\mathrm{g} \mathrm{m}^{-2}\right)$. 'Group' refers to the organic and conventional groups of systems, 'treatment' to the cropping systems within the two groups.

\begin{tabular}{lccc}
\hline Source & df & \multicolumn{2}{c}{ p-value } \\
\cline { 3 - 4 } & & ind. $\mathrm{m}^{-2}$ & dwt g m${ }^{-2}$ \\
\hline Group & 1 & 0.275 & 0.689 \\
Treatment (Group) & 6 & 0.443 & 0.442 \\
Replicate & 2 & 0.131 & 0.165 \\
Replicate $\times$ Group & 2 & 0.037 & 0.036 \\
\hline
\end{tabular}

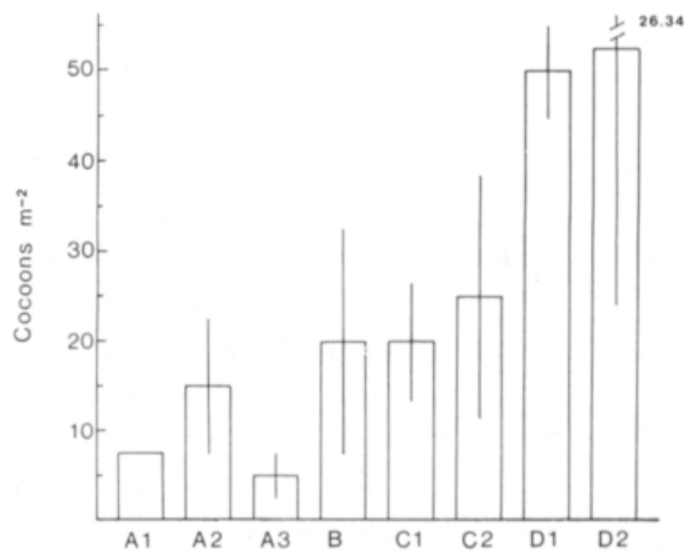

Fig. 4. Number of cocoons (coc. $\left.\mathrm{m}^{-2}( \pm \mathrm{SE})\right)$ in 1988. The estimates are based on three replicate means each based on four soil-core-samples. The symbols of the cropping systems are explained in the text.

cocoon data, owing to the great heterogeneity of variances.

\section{Size of A. caliginosa}

The mean dry weights (mg (SE)) of adult A. caliginosa in different cropping systems were between $96(8.6)$ and 136 (22.6). For juveniles the minimum average dry weight was 18 (1.5) and the maximum 32 (4.8). Organic and conventional groups did not differ (adults: $\mathrm{p}=0.509$; juveniles: $\mathrm{p}=0.085$ ), nor did the cropping systems within the organic and conventional groups (adults: $\mathrm{p}=0.279$; juveniles: $\mathrm{p}=0.620$ ).

\section{Discussion}

\section{Sampling method}

The formalin method did not always work satisfactorily in the prevailing conditions. Particularly at the sites where the soil was unusually compacted, and when the soil was very moist, infiltration of the solution was poor. This made the picking of worms difficult, and at times the solution spread outside the sampling square. Very often no earthworms emerged during the last application of forma- 
lin, and it seems evident that less solution would have been enough.

\section{Yearly changes in abundance}

There is no guarantee that the efficiency of the formalin method was similar in the different weather conditions of the three autumns. The low total catch of individuals in 1987 may reflect a real population low or a failure in sampling caused by the unusually wet conditions where the sampling was done, or a combination of the two. One possible explanation for the low numbers in 1987 is the very cold winter of 1986-87 (HANNUKKALA et al. 1990, Fig. 5). The frost that occurred about a week before the sampling in 1987 may also have affected the result. Winter mortality of earthworms is known to be high in Northern Scandinavia (Возтво̆м 1988), and a similar reduction in earthworm abundance on arable land was observed elsewhere in Southern Finland during the same period (personal observations).

It is difficult to distinquish the effects of weather conditions from those of the crop sequence, and the consistency of any possible pattern cannot be established as only part of a crop sequence was sampled once. The low abundances in 1987 at A3, C1 and C2 may have been due to the phase of the crop sequence; potato was grown in all of the plots that year. As the estimates in two of the plots were no longer low in the following year, it is possible that the formalin extraction simply worked particularly poorly in the potato plots in 1987. However, repeated cultivations in potato fields are known to be harmful to soil fauna. In addition, low dehydrogenase activities and low levels of nitrification were observed in 1987 in the potato plots (HEINONENTANSKI 1990), indicating low overall biological activity in the soil.

More intensive sampling than here is needed to monitor earthworms in agricultural rotations. Earthworm populations react rapidly to changes in the environment (LoFs-HoLmiN
1983 a, Воsтröм 1988), and non-conclusive sampling may lead to erroneous conclusions.

\section{Species}

The earthworm fauna of the experimental field is typical of cultivated soils of Southern Finland (Terhivuo 1988). The dominance of $A$. caliginosa is not surprising. In its whole area of distribution, it is among the species most able to persist in arable land (EDwARDS 1983). This is due to its endogeic habits. It feeds on decomposing below ground organic matter, which is available even under heavy cultivation. Due to its facultative diapause (Evans and Guild 1947), the species can tolerate the relatively strong and rapid temperature and moisture changes typical of cultivated soil. Good ability of regeneration increases the ability of the population to recover from the direct damage which cultivation may cause to individuals (ВозтRöм 1988).

Litter dwelling (epigeic) species were scarce. They were represented to any considerable degree only by $L$. rubellus. This is understandable, as the cropping systems poorly provide the litter habitat which the species needs. Deep burrowing (anecic) L. terrestris was also very scarce. The populations of epigeic and anecic species have evidently been low already during the previous cultivation (HANNUKKALA et al. 1990) of the field. Either the cropping systems are not suitable for them, or the time from the start of the experiment was too short for them to enter the field. The following points support the first alternative in the case of $L$. terrestris.

In October 1989, the small piles of mixed surface casts and collected litter, a typical sign of the presence of $L$. terrestris, were abundant on the ditch banks of the experimental field. As $L$. terrestris is able to disperse rapidly over relatively long distances (MATHER and CHRISTENSEN 1988), it is reasonable to assume that the prevailing conditions on the field keep its populations low. The ploughing destroys its permanent burrows and buries the majority of the surface residue, the normal food of 
adult $L$. terrestris. Results obtained elsewhere show that when organic farming is accompanied by minimized tillage, the populations of L. terrestris do increase (EL TITI and IPACH 1989). Another negative factor is the locally strong compaction of the experimental field. Compaction affects adversely also $A$. caliginosa (Boströм 1986), but it seems to cause more difficulty to the burrowing of $L$. terrestris (RUSHTON 1986, personal observations). It has also been shown by ANDERSEN (1980) that slurries, the animal manure of our experiment, can have deleterious effects on anecic earthworms. He related this to the toxicity of the liquid penetrating into the burrows. It is possible that the low relative proportion of genus Lumbricus, which was observed in the slurry amended systems in the present study, is due to the same effect.

\section{Abundances in 1988}

As discussed elsewhere in more detail (Konva et al. 1990), the variation in the topography and drainage of the experimental field introduced an uncontrolled factor into the experiment. Parts of the field were periodically water-logged and covered with ice during winters. The areas with worst drainage problems were in the flat area covering the organic side of replicate II and the majority of the organic side in the replicate III (for the field map see HannUKKala et al. 1990, Fig. 2 ). During the sampling in 1988 , the poor soil structure in these areas was evident.

The highest total dry weight of the field was observed in D2 (organic vetch mixture) of replicate III. The plot lay on the sloping region, outside the flat area. The plots with the second (B; conventional ley) and third (D1; organic vetch mixture) highest abundances of replicate III were both right next to D2. In replicate II the abundance was highest in A2 (conventional barley), which lay towards the south end of the replicate, where the soil surface starts to slope to the river. Also in replicate II the plots with the second (B; conventional ley) and third (A1; conventional barley) highest abundances lay next to the plot with the highest abundance. In replicate I the highest abundances were considerably lower than in II and III, and there was no clear area of high abundance.

The drainage problems in the central area of the field possibly caused the very different response of earthworms in the replicates, and thus contributed to the significant interaction between replicate and group of systems (Table 1). Earthworms are known to flee from flooding, and areas of prolonged water-logging have low population densities and little signs of earthworm activity (BOONE et al. 1976, CARTER et al. 1982). Further, poorly drained clayey soils easily get compacted, and this also stresses the earthworms (Boström 1986).

In general, the abundance of earthworms in 1988 was of the same order of magnitude as reported for cultivated soils elsewhere in Scandinavia. Возтröм (1988) studied earthworms in an experiment on cultivated loam soil with sampling methods comparable to ours. In her study the number of earthworms under fertilised and unfertilised barley were on average slightly over 30 and in grass ley slightly below 50 ind. $\mathrm{m}^{-2}$. The abundance was highest, a little over 160 ind. $\mathrm{m}^{-2}$, in lucerne ley. Comparison with our biomass estimates is difficult because of methodological differences. $A$. caliginosa was as dominant as in our material.

The effects of different fertilisers on earthworm abundance have usually been attributed to changes in the amount of available food (EDwards 1983). As fertilisers affect the plant production, they also tend to influence the amounts of crop residues below and above ground, the food of detrivores. Organic fertilisers, such as farmyard manure (FYM), slurries and green manures, do not only influence plant production but are themselves earthworm food. The variety of fertilisers and the conditions in which they are used have led to differening conclusions on the effects of fertilisation on earthworms, particularly so in the case of inorganic fertilisers (LeE 1985, BoSTRÖM 1986). EdWARDS and LOFTY (1982) 
reported a positive correlation between the amounts of inorganic $\mathrm{N}$ applied and the abundance of earthworms in crop cultivations. The increase was strongest in the endogeic species, which consume organic matter below ground. The greatest total increase was observed when both inorganic $\mathrm{N}$ and FYM were applied, this being partly due to the increase in L. terrestris. Lofs-Holmin (1983 b) studied earthworms in a clayey field, and did not observe any relationship between the quality or quantity of inorganic $\mathrm{N}$-fertilisers and earthworm abundance. A rapid temporary increase in the population density of $A$. caliginos $a$ after FYM application was observed (LoFs-HoLmin 1983 a).

One factor contributing to the relatively uniform abundances in our cropping systems in 1988 could be that the low crop yields, and thus lower production of food for earthworms, in the organic plots (KoRvA and VARIS 1990) were partly compensated by the organic manures and higher production of weeds in organic plots (KauppILA 1990). As there were no measurements of the soil organic matter content, this assumption cannot be verified. The similar size of the dominant A. caliginosa in different cropping systems suggests that the living conditions in them were not very different with regard to the endogeic earthworm. However, the high number of cocoons together with the high proportion of juvenile $A$. caliginosa in the vetch mixtures D1 and D2 fertilised with slurry indicate to strong production of offspring in these systems. It is known that cocoons are produced more by earthworms feeding on animal dung than by those fed with plant litter (Evans and GuILD 1948). In addition, soil conditions under leguminous leys are regarded suitable for annelids, as the tap roots of legumes penetrate deep and do not dry the top soil as heavily as grass roots (BATES 1933, LAGERLÖF et al. 1989).

A number of fungicides potentially harmful to earthworms were used at Suitia in conventional cropping. The seed of the cereals was treated with mercury and tiophanate- methyl based fungicides. In 1987, tiabendazol was applied on potato seed tubers, and in 1984 and 1987 , potato was sprayed with copper oxychloride. All four substances are harmful to earthworms even at normal dose rates (LEE 1985), although we do not know whether the effects of seed treatments have been studied. The effects of the applications cannot be judged reliably on the basis of our material.

In farm surveys, organic farms were observed by GeHLEN and SCHRöder (1985) to have higher earthworm abundances than conventional farms, while KLEYER and BABEL (1984) did not find clear differences in the soil characteristics of organic and conventional farms caused by the earthworms. Our results cannot be compared with these in any straightforward manner, as the studied agricultural rotations, cultivation practices and environmental conditions differ widely. TROLLDENIER (1987) reviewed the literature on the soil life in different cropping systems and concluded that neither of the two farming systems (conventional vs. organic) is definitely 'superior' from the soil biological point of view. Our estimates of earthworm abundance from 1988, together with the slight qualitative differences in the earthworm communities, seem to be in line with his view. It is unlikely that there would be any consistent differences in the soil conditions of the cropping systems at the Suitia experiment which could be explained by the activity of earthworms. However, bearing in mind the considerable uncontrolled variability in the soil conditions of the field, the result cannot be generalized.

Acknowledgements. We thank Rauno Ukkola, Erja Huusela-Veistola and Simo Veistola for their help with the sampling and treatment of the material, Jukka Korva and Asko Hannukkala of the Suitia Project for helpful discussions, Jari Heikkilă, Helvi Heinonen-Tanski and Veikko Huhta for commenting on the manuscript, Sevastiana Ruusamo for improving the English and the personnel of the Suitia Farm for logistic support. The study is a part of the project 'The role of soil macrofauna in field crop cultivation' funded by the National Research Council for Agriculture and Forestry of the Academy of Finland. 


\section{References}

ANDERSEN, C. 1980. The influence of farmyard manure and slurry on the earthworm population (Lumbricidae) in arable soil. In: Soil biology as related to land use practices (Ed. D. Dindal), pp. 325-334. Proc. VIIth Int. Soil Zool. Coll., Syracuse, USA. EPA Washington DC: 560/13-60-038.

Andrén, O. \& SteEn, E. 1978. Bekämpningsmedlens inverkan på markens organismer. 1. Djurlivet. 95 pp. SNV PM 1082, Stockholm.

Arden-Clarke, C. \& Hodges, R.D. 1988. The environmental effects of conventional and organic/biological farming systems. II. Soil ecology, soil fertility and nutrient cycles. Biol. Agric. Hortic. 5:223-287.

BATES, G.H. 1933. The distribution of wild white clover (Trifolium repens) in relation to the activity of earthworms (Lumbricidae). Welsh J. Agric. 9: 195-208.

Boone, F.R., Slager, S., Miedema, R. \& Eleveld, R. 1976. Some influences of zero-tillage on the structure and stability of a fine-textured river levee soil. Neth. J. agric. Sci. 24: 105-119.

Bostróm, U. 1986. The effect of soil compaction on earthworms (Lumbricidae) in a heavy clay soil. Swed. J. agric. Res. 16: 137-141.

Bostrò, U. 1988. Ecology of earthworms in arable land. Population dynamics and activity in four cropping systems. Dissertation. Swed. Univ. Agric. Sci., Dept. Ecol. Environ. Res., Report 34.

BOUChE, M.B. \& GARDNER, R.H. 1984. Earthworm functions VIII. Population estimation techniques. Rev. Ecol. Biol. Sol 21: 37-63.

Bouche, M.B., Haimi, J. \& Huhta, V. 1988. Two earthworm taxa (Oligochaeta, Lumbricidae) new to Finland. Memoranda Soc. Fauna Flora Fennica 64: $65-67$.

Carter, A., Heinonen, J. \& De Vries, J. 1982. Earthworms and water movement. Pedobiol. 23: 395-397.

EDwards, C.A. 1983. Earthworm ecology in cultivated soils. In: Earthworm ecology. From Darwin to vermiculture (Ed. J.E. Satchell), pp. 123-137. Chapman and Hall, London.

Edwards, C.A. \& Lofty, J.R. 1982. Nitrogenous fertilizers and earthworm populations in agricultural soils. Soil. Biol. Biochem. 14: 515-521.

El. TITI, A. \& IрACH, U. 1989. Soil fauna in sustainable agriculture: Results of an integrated farming systems at Lautenbach, F.R.G. Agric. Ecosystems Environ. 27: $561-572$.

Evans, A.C. \& Mcl. Guild, W.J. 1947. Studies on the relationships between earthworms and soil fertility. I. Biological studies in the field. Ann. Appl. Biol. 34: 307-330.

Evans, A.C. \& Mcl. Guild, W.J. 1948. Studies on the relationships between earthworms and soil fertility. IV. On the life cycles of some British Lumbricidae. Ann. Appl. Biol. 35: 471-484.
Gehlen, P. \& SChróder, D. 1985. Enzymtätigkeiten, mikrobielle Biomasse und Regenwurmbesatz in "biologisch" und "konventionell"' bewirtschafteter Boden unterschiedlicher Nutzung. Mitteilgn. Dtsch. Bodenkundl. Geschellsch. 43/II: 643-648.

HeInONEn-TANSKI, H. 1990. Conventional and organic cropping systems at Suitia III: Microbial activities in soils. J. Agric. Sci. Finl. 62: 331-337.

KAUPPILA, R. 1990. Conventional and organic cropping systems at Suitia IV: Weeds. J. Agric. Sci. Finl. 62: $00-00$.

Kleyer, M. \& BABel, U. 1984. Gefügebildung durch Bodentiere in "konventionell" und "biologisch"' bewirtschafteten Ackerböden. Z. Pflanzenernaehr. Bodenk. 147: 98-109.

Hannukkala, A.O., Korva, J. \& Tapio, E. 1990. Conventional and organic cropping systems at Suitia I: The experimental design. J. Agric. Sci. Finl. 62: 295-307.

Korva, J. \& VARIS, E. 1990. Conventional and organic cropping systems at Suitia II: Crop growth and yields. J. Agric. Sci. Finl. 62: 309-319.

Lagerlöf, J., Andrén, O. \& Paustian, K. 1989. Dynamics and contribution to carbon flows of Enchytraeidae (Oligochaeta) under four cropping systems. J. Appl. Ecol. 26: 183-199.

LEE, K.E. 1985. Earthworms. Their ecology and relationships with soils and land use. $411 \mathrm{pp}$. Acad. Press, Sydney.

Lofs-Holmin, A. 1983 a. Earthworm population dynamics in different agricultural rotations. In: Earthworm ecology. From Darwin to vermiculture (Ed. J.E. Satchell), pp. 151-160. Chapman and Hall, London.

Lofs-Holmin, A. 1983 b. Influence of agricultural practices on earthworms (Lumbricidae). Acta Agric. Scand. 33: 225-234.

Mather, J.G. \& Christensen, O. 1988. Surface movements of earthworms in agricultural land. Pedobiol. 32: 399-405.

McCullagh, P. \& Nelder, J.A. 1983. Generalized linear models. 261 pp. Chapman and Hall, London.

Rushton, S.P. 1986. The effects of soil compaction on Lumbricus terrestris and its possible implications for populations on land reclaimed from open-cast coal mining. Pedobiol. 29: 85-90.

Sims, R.W. \& Gerard, B.M. 1985. Earthworms. Synopses of British Fauna No. 31. 171 pp. The Linnean Soc. of London \& the Estuarine and Brackish-Water Sci. Assoc.

Terhivuo, J. 1988. The Finnish Lumbricidae (Oligochaeta) fauna and its formation. Ann. Zool. Fennici 25: $229-247$.

Trolldenier, G. 1987. Influence of cultivation measures on soil life. Pl. Res. Devel. 26: 114-126.

Ms received March 28, 1990 


\section{SELOSTUS}

\section{Suitian viljelyjärjestelmät \\ VII: Lierot}

\section{Visa Nuutinen ja Jari Haukka*}

Maatalouden tutkimuskeskus,

Kasvinsuojelun tutkimuslaitos,

31600 Jokioinen

* Nykyinen osoite: Kansanterveyslaitos, Kalliolinnantie 4, 00140 Helsinki

Tutkimme lierojen runsautta ja lajistoa Suitian koetilalla Siuntiossa kokeessa, jossa verrattiin neljăă tavanomaista ja neljäă luonnonmukaista viljelyjärjestelmaaả hiesusavikentaallä. Näytteită otettiin seitsenvuotisen kokeen viidentenă (1986) ja kuudentena (1987) syksynă formaliinimenetelmăllă yhdestă kerranteesta ja viimeisenă syksynă (1988) formaliini-huuhtelunăyte-menetelmăllă kaikista kolmesta kerranteesta.

Peltoliero (A porrectodea caliginosa) oli selvästi yleisin laji kaikissa viljelyjärjestelmissă. Lajin yksilöt olivat kooltaan samanlaisia eri viljelyjärjestelmissả. Muut koekentăllă esiintyneet lajit olivat kasteliero (Lumbricus terrestris), onkiliero ( $L$. rubellus) sekä hyvin harvalukuinen ruskoliero ( $L$. castaneus). Tavanomaisten ja luonnonmukaisten viljelyjärjestelmien lieroyhteisőissă ei havaittu selviả eroja. Lietelannan levittäminen oli văhentănyt Lumbricussuvun lierojen osuutta.

Lierojen runsaudessa havaittiin vuosittaista vaihtelua, jonka syită on vaikea osoittaa tarkasti. Viljelykierron vaihe, säăolojen muutokset ja nãytteenottomenetelmăn tehokkuuden vaihtelu ilmeisesti kaikki vaikuttivat runsausarvioihin. Vuonna 1987 havaittiin yleisesti alhaisia tiheyksiä, mikä mahdollisesti johtui edeltäneen talven poikkeuk- sellisesta kylmyydestä. Vuoden 1987 alhaisimmat lierotiheydet mitattiin perunaa kasvaneissa ruuduissa.

Vuonna 1988 lierojen lukumaaără oli (suluissa keskiarvon keskivirhe) 23 (11.2) - 92 (49.8) yksilöă $\mathrm{m}^{-2}$ ja kokonaiskuivapaino $1.0(0.54)-3.2(1.53) \mathrm{g} \mathrm{m}^{-2}$. Lierojen munakoteloiden măără vaihteli vălillă $5(2.5)-52.5$ (26.3) $\mathrm{m}^{-2}$. Runsaudet olivat suurimmillaan luonnonmukaisesti viljellyllă virnanurmella. Viljelyjärjestelmät eivăt poikenneet tilastollisesti merkitsevästi toisistaan lierojen runsaudessa. Ainoa merkitsevä vaihtelun lähde oli vuorovaikutus hierarkkisen koejärjestelyn ylimmän tason (tavanomaiset vs. luonnonmukaiset viljelyjärjestelmăt) ja kerranteen vălillă $(\mathrm{p}=0.04)$. Tuloksen selittänee kentän ojitusongelmien aiheuttama huomattava vaihtelu eri kerranteiden olosuhteissa. Pääosa kahden kerranteen luonnonmukaisesti viljellyistă ruuduista sijaitsi alueella, joka oli veden vaivaama, tiivistynyt ja talvisin jäăn peitossa. Tămă oli ilmeisesti văhentănyt lieroja vaikeuttaen kăsittelyjen vaikutusten arviointia.

On epätodennäköistả ettả kokeen viljelyjärjestelmien maan laadussa olisi systemaattisia lierojen toiminnan aiheuttamia eroja. Kentăn kuivatusongelmien vuoksi ei havaintojamme lierojen runsaudesta eri viljelyjärjestelmissă voi yleistăaa. 